DOI: https://doi.org/10.32839/2304-5809/2020-2-78-90

UDC 372.881.111.1

Lakiychuk Olga, Nypadymka Anna

National Technical University of Ukraine

"Igor Sikorsky Kyiv Polytechnic Institute"

\title{
MOTIVATIONAL ASPECT IN TEACHING ESP IN HIGHER EDUCATION INSTITUTION
}

Summary. The importance of foreign language acquisition, English for specific purposes, in particular, is undoubtedly high, since the new political situation, the soaring extension of international cooperation, and participation in international projects and conferences require a deeper knowledge of English. Maintaining motivation to learn any foreign language within the students of technical specialities, who, in most cases, are not interested in linguistics and humanitarian subjects in general, is one of the main problems and challenges for a teacher in the process of teaching methods selection. The present paper defines the concept of motivation, presents different types of it, and describes the importance of inner or self-motivation of the non-linguistic specialities students, who learn ESP. The paper also presents some ideas for activities, which can be conducted within the ESP classroom, aimed at enhancing the students' desire to learn any foreign language and boosting internal self-motivation.

Keywords: motivation, internal motivation, ESP, language level advancement, language competences.

Лакійчук О.В., Нипадимка А.С. Національний технічний університет України «Київський політехнічний інститут імені Ігоря Сікорського»

\section{МОТИВАЦІЙНИЙ АСПЕКТ У ВИКЛАДАННІ ІНОЗЕМНОЇ МОВИ ПРОФЕСІЙНОГО СПРЯМУВАННЯ У ВИЩОМУ НАВЧАЛЬНОМУ ЗАКЛАДІ}

\begin{abstract}
Анотація. Важливість вивчення іноземної мови не викликає сумнівів, зважаючи на нову політичну ситуацію, розширення міжнародної співпраці та контактів, участь у міжнародних конференціях за участю іноземців вимагають від студентів глибших знань іноземних мов, зокрема англійської мови професійного спрямування. Більш того, рівень володіння англійською мовою прямо пропорційно впливає на заробітню плату. Щоб досягти прогресу та успіху у вивченні іноземної мови, як і будь-якої іншої дисципліни, необхідно мати бажання та мотивацію. Розвиток мотивації вивчати англійську мову та їі підтримання на гідному рівні є однією з головних проблем, пов'язаних з вибором методів навчання, видів завдань як для класного так і індивідуального позакласного виконання, оскільки студенти технічних спеціальностей, у більшості випадків, не цікавляться лінгвістикою та гуманітарними науками загалом. У цій роботі розкрито та визначено поняття мотивації, продемонстровано типи мотивації. Зокрема розглянуто способи підвищення внутрішньої мотивації, оскільки студенти вищих навчальних закладів забезпечені зовнішньою мотивацією, тобто вони виконують тести поточного та підсумкового контролю, отримують бали для проходження атестацій, та підвищення рейтингу, що впливає на отримання або неотримання стипендії. При опитуванні, студенти, що вивчають фізику та математику, як основні дисципліни, визнали, що зовнішня мотивація та тиск дуже ефективні, проте без наявності бажання, натхнення та само мотивації знання залишаються в рамках університету, тобто на короткий період часу. Метою даної роботи є розгляд ролі мотивації у вивченні іноземної мови, її основних складових та впливу мотивації на навчальний процес, а саме ефективності оволодіння іноземною мовою студентами вищих навчальних закладів. В роботі також запропоновані види робіт, що орієнтовані на підвищення особистої мотивації студентів вищих навчальних закладів технічного спрямування. В статті представлено деякі ідеї завдань, які можна виконувати на заняттях з іноземної мови, зокрема професійного спрямування, з метою посилення само мотивації студентів нелінгвістичних спеціальностей та їх зацікавлення у вивченні іноземної мови.
\end{abstract}

Ключові слова: мотивація, само мотивація, іноземна мова професійного спрямування, мовні навички.

$\mathrm{P}$ roblem statement. At the present stage of social development, taking into account the globalization process of all spheres of public relations, significant attention to foreign language acquisition is being paid. The globalization process means that the role of the social contacts is becoming increasingly important as well as verbal communication, including inter-ethnic communication, which requires knowledge of a foreign language [1, p. 49]. Therefore, the issue of students' motivation enhancement in the process of studying foreign languages is becoming absolutely necessary, and quite relevant. Insufficient motivation appears to be a particular difficulty and a significant obstacle in the language learning process, particularly in dealing with English for Specific Purposes (ESP).
Often, even well-developed modern non-native language teaching methods are found to be poorly performed if they cause the negative emotions of the students and do not provoke any interest, which causes the diametrically opposite mental states among the students of non-linguistic specialities: a state of boredom or condition of anxiety. For example, the students who are not motivated to attend a foreign language class can get bored during the lesson and are far from seeking to master communicative skills on a sufficient level, and anxiety is felt by those who are afraid to make a mistake, unsure of themselves, have great psychological barrier, but still have not lost the desire to master a foreign language. A foreign language as a discipline that has a great number of specific features and one of them is acquiring the ability to 
communicate. Therefore, there is a constant need to develop or investigate teaching methods which can work efficiently on the development of students' motivation.

Further research, the study of peculiarities of motivation, development of new approaches, programmes and curricula will allow improving and rationalizing the educational process and enhance the achievement of perfectly better results.

The objective of this paper is to underline and highlight the role of motivation in learning ESP, define the concept "motivation" and present its components, and the reveal the motivation impact on the educational process, namely the effect of advancing foreign language skills by the students of higher education institutions. In addition, the present paper suggests the ideas and ways of a substantial increase in the motivation level of the higher institutions students, who study technical specialities.

Analysis of recent research and publications. Motivation is the greatest success factor in studying as a whole and, particularly, in learning the second language. All the actions made by any person, such as cognition, work, communication are launched by the internal or external need or motivation. Many researchers have already analysed the motivational process, among them, are the following: S. Zanyuk [4], Gotlib R.A. [2], Alizadeh M. [9], Dornyei Z. [12], Ditual R.C. [11], Chang L.Y.H. [10], and many other linguists and psychologists. In their studies, the mentioned above scientists revealed the essence of the concept "motivation" and implemented modern approaches to the problem of motivation to bring culture to the first place where one of the basic aspects is the ability to navigate the socio-cultural environment of the country being studied [3, p. 57]. Such figures as Zoltan Dornyei and Emma Usioda thoroughly investigated the types and methods of motivational research, analysed the basics of internal motivation during the study of foreign languages and ways of learning enhancement [12]. Mitra Alizadeh highlighted the three key factors of motivation, stating that students should have a positive attitude towards the community of the second language; they should enjoy the process and have external pressure [9].

In the process of teaching a very important role is played by the level of professional and pedagogical communication of the teacher. According to I. Zimnaya, laxity, lack of a fear, joyful attitude towards the teacher, learning, and the desire for friendly understanding in the group is the result of the correct style of communication chosen by the teacher. The author also notes that the educational process may be organized on the highest level substantially and methodologically, it can be nullified with an inadequate style of the pedagogical communication [5, p. 203].

The results of studies presented in the scientific literature highlight that there are significant problems in providing conditions for a successful motivation to ensure successful educational activities of students. And despite the fact that modern psychologists have certain experience in the field of theoretical foundations of motivation, general understanding of the relationship between motivation and learning activities, as well as their impact on the effectiveness of learning and its mechanisms.
The problem of ensuring the purposefulness of students' motivation formation remains insufficiently disclosed, and the ways of enhancing the motivation of the non-linguistic specialities students, except for providing them with external pressure still need to be discovered.

Main material. Today, foreign language skills are already becoming a compulsory component of professional activity. Taking into account the importance of the role of motivation, as an integral part of learning a foreign language by the students of technical specialities from the non-linguistic universities, the teacher needs to be confident about the ways and methods that can be applied within an ESP classroom in a certain university. Therefore, it is considered wrong to simplify the understanding of the motivation when considering the issues of its development and searching ways of its creation, because the formation of motives is, first and foremost, ensuring of conditions for the personification of internal learning motivations, students' self-awareness and the further self-development.

Thus, in mastering a foreign language culture, it is interesting to find out what motives drive the student to implementation of activities. The knowledge transfer from teacher to a student cannot be effective without the activity of the student himself, so learning motivation is a necessary component in the successful process mastering a foreign language [8, p. 132].

Defining the term "motivation" and studying its components and classification can provide the solution and understanding of the basic principles of provoking students' interest and boosting their motivation to learn ESP.

The word "motivation" has got the Latin origin, which initially sounds as "movere", and is defined in the Oxford dictionary as the reason and drive to action, the dynamic process of physiological and psychological plan that controls the behaviour of a person, determines his orientation, organization, activity and fatigue; a person's ability to meet his or her needs for action [13].

Having observed and questionnaired several focus groups of students, who study Maths and Physics at the National Technical University of Ukraine, "Igor Sikorsky Kyiv Polytechnic Institute", there was made a conclusion, that external motivation, such as grades, exams, fear to lose their scholarships and pressure from their parents, is the most powerful. But, nevertheless, these students assume, that the language learning process would be much effective, providing that they had no external but pressure but only self-motivation, such as personal interest and pleasure from the activities done within the classroom. Self-motivation can also be called as the intrinsic or inner motivation and this type of motivation may provide long-term success. Therefore it is necessary to consider the main varieties of an individual's inner motivation for learning a foreign language.

The communicative kind of inner motivation is considered to be basic because communication is the first and natural need of a person on the way of learning a foreign language. Special sociological surveys show that regardless of age and social status the students consciously and unanimously formulate their needs as purely communicative, 
namely, to speak in a foreign language with colleagues, friends, to be able to read with the purpose of expanding outlook, as with a professional purpose, and for your own pleasure, to write in a foreign language to friends, colleagues.

However, despite such a strong interest in communicating in a foreign language, this type of motivation is the hardest thing to keep. This is because during mastering a foreign language in an atmosphere of the native language the foreign language is emerging as an artificial means of communication. Thus, all the so-called "natural situations" have an artificial character. Taking this fact into account, the different communicative approaches were applied and tested on the mentioned above focus groups of students. The students demonstrated great interested when they were offered various gamification activities, brainstorming sessions, brain rings, and critical thinking development tasks. In such situations, they have a sense of competition and the ability to express themselves, their ideas, opinions, creativity.

The next kind of inner motivation should be considered linguistic, which lies in the positive students' attitude to the most "linguistic matter", to the study of the basic qualities of linguistic signs. There are two possible ways of its formation: indirect, through communicative motivation, and direct, by stimulating student search activity in language material. In order to develop this type of motivation, the students were offered two months to search for interesting facts about their area of expertise and then organise a quiz for the group mates. Such task had great success, due to the fact that they feel the great interest towards their speciality, and the need to share and exchange interesting pieces of information, data and facts. The project was accomplished with debates and discussion.

An important form of inner motivation is also an instrumental one, that is, the motivation that stems from the positive attitude of students to certain types of work.

In recent years, the attention of many researchers in the field of the methodology and innovative technologies in foreign language teaching is paid to the use of Internet resources. Student observations and surveys have demonstrated that the use of multimedia significantly increases motivation, positively influences the desire to learn a foreign language $[6, p .26]$. The use of the new information technologies in teaching ESP cannot be overestimated due to the fact that world wed offers a large number materials, hand-outs, worksheets, and multimedia resources, that can simplify the lessons preparation process, increases the effectiveness of learning in general, provides the possibilities of remote and individual education.

In addition, according to Jacobson P., it provides effective visualization of the educational process [8, p. 97].

Using multimedia by the teachers to create presentations of lesson sections will help to revitalize the educational process, $[7$, p. 7] thus the teachers might demonstrate interactive presentations, made with the help of such website, as for instance, mentimeter.com. This website offers the easy creation of presentation on any topic, thus an ESP teacher has got the opportunity to select materials relevant to the topic of the particular lesson. Therefore the focus group of students worked with interactive presentations and demonstrated excellent results and positive feedback. In addition, they were given interactive tasks, such as quizzes and puzzles, using resources like kahoot.com, quizlet.com, classtime.com. These websites offer great assistance for the teachers in creating multimedia interactive activities and have a wide range of options for conducting interesting and useful ESP lessons. Nevertheless, the disadvantage of using such tools is the lack of equipment in the classrooms and poor internet connection. But despite these negative aspects, using such resources is extremely beneficial; they can be used both within the classroom and individually at home. Moreover, there is a great number of sites offering free online tasks on grammar and vocabulary. Students reported that they have got a great motivation to fulfil the task if they see an instant result and when the task completion is not time-consuming and can be done while commuting.

Conclusions. It is very difficult for high school teachers to persuade adult students in the importance of learning a foreign language, especially if linguistics is not the students' area of expertise, and they have the lack of time and desire to pay attention to humanitarian subjects such as languages. Moreover, the teachers of the special disciplines should combine their efforts with foreign language teachers and in every way contribute to the growth of the positive motivation for learning a language.

It is known that pedagogical effect can be achieved to a greater extent as a result of one's own activity of the students, and cannot be obtained in the form of neutral passive perception, thus internal motivation and desire play a significant role in the achievements of positive results and long-term success. It is necessary to equip the students with certain techniques of self-mastering a foreign language so that their rational sense was felt and impressed them, therefore such factors as selecting interactive activities and teachers' positive attitude should be taken into consideration.

\section{References:}

1. Gordienko, M.G. (2003). Inozemna mova yak zasib pidvyzhchennia konkurentnoi zdatnosti ta mobilnosti suchasnogo fahivtsia [Foreign language as a mean of enhancing the competitiveness and mobility of the modern specialist]. Linguomethodical concepts of teaching foreign languages in non-linguistic higher educational establishments. Kyiv: European University Publishing, pp. 49-55. (in Ukrainian)

2. Gotlib, R.A. (2009). Socialnaya vostrebovannost znaniya inostrannogo yazyka [Social demand on foreign language knowledge]. Social studies, no 2, pp. 122-127. (in Russian)

3. Davydenko, U.Y. (2005). Vykorystannia informatsiyno-comunicatyvnyh tehnologiy dlia movnoii osvity [The use of information and communication technologies for the linguistic education]. Foreign languages, pp. 67-68. (in Ukrainian)

4. Zaniuk, S.S. (2000). Pochuttia competentnosti u studentiv ta uchniv yak component motyvatsii uchinnia [The feeling of competence of the students and schoolchildren as a component of learning motivation]. The problems of general and pedagogical phycology. Scientific scientific papers collection of G.S. Kostiuk Institute of Phycology of the National Academy of Educational Sciences of Ukraine. P. 2. Kyiv: Volynski Beregy, pp. 153-161. (in Ukrainian) 
5. Zimniaya, I.A. (2004). Pedagogicheskaya Psyhologiya [Pedagogical Phycology]. Moscow: Logos, 384 p. (in Russian)

6. Ogurtsova, O.L. (2006). Navchannia dilovoi angliiskoi movy z vykorystanniam Internet resursiv [Using internet resources in learning business English]. Foreign Languages, no 4, pp. 26-29. (in Ukrainian)

7. Skalii, L.I. (2003). Vykorystannia informatsiynyh tehnologiy [Information technologies application]. Foreign Languages, no 4, pp. 7-8. (in Ukrainian)

8. Yakobson, P.M. (1988). Psihologicheskiye problemy motivatsii povedeniya cheloveka [Phychological problems of behavior motivation]. Moskow: Prosviaschenie, 224 p. (in Russian)

9. Alizadeh, M. (2016). The Impact of Motivation on English Language Learning. International Journal of Research in English Education. Vol. 1, No. 1. Retrieved from: http://ijreeonline.com/article-1-23-en.pdf

10. Chang, L.Y.H. (2010). Group Processes and EFL Learners' Motivation: A Study of Group Dynamics in EFL Classrooms. TESOL Quarterly, 44, 129-154. doi: 10.5054/tq.2010.213780

11. Ditual, R C. (2012). The Motivation for and Attitude towards Learning English. Asian EFL Journal Press 2012 , 63. P. 4-21.

12. Dornyei, Z. \& Ushioda, E. (2001). Teaching and Researching Motivation. Applied Linguistics in Action Series. $2^{\text {nd }}$ edition, Pearson Education Limited. Retrieved from: https://archive.org/stream/ilhem_20151031_1015/\%5B Zolt\%C3\%A1n_D\%C3\%B6rnyei\%2C_Ema_Ushioda\%5D_Teaching_and_Resea_djvu.txt

13. Oxford University Press (2020). Motivation. Oxford Advanced Learner's Dictionary. Retrieved from: https://www.oxfordlearnersdictionaries.com/definition/english/motivation?q=motivation

\section{Список літератури:}

1. Гордієнко М.Г. Іноземна мова як засіб підвищення конкурентої здатності та мобільності сучасного фрахівця. Лінгвометодичні концепції викладання іноземних мов у немовних вищих навчальних закладах України. Київ : Видавництво Європейського університету, 2003. С. 49-55.

2. Готлиб Р.А. Социальная востребованность знания иностранного языка. Социологические исследования. 2009. № 2. C. 122-127.

3. Давиденко Ю.Є. Використання інформаційно-комунікативних технологій для мовної освіти. Іноземні мови. 2005. С. 67-68.

4. Занюк С.С. Почуття компетентності у студентів та учнів як компонент мотивації учіння. Проблели загальної ma педагогічної психологї. Збірник наукових праць Ін-ту психології імені Г.С.Костюка АПН України. Ч. 2. Київ : Волинські обереги, 2000. С. 153-161.

5. Зимняя И.А. Педагогическая психология. Москва : Логос, 2004. 384 с.

6. Огурцова О.Л. Навчання ділової англійської мови з використанням Інтернет-ресурсів. Іноземні мови, 2006. № 4. C. 26-29.

7. Скалій Л.І. Використання інформаційних технологій. Інозелні мови. 2003. № 4. С. 7-8.

8. Якобсон П.М. Психологические проблемы мотивации поведения человека. Москва : Просвещение, 1988.224 с.

9. Alizadeh M. The Impact of Motivation on English Language Learning. International Journal of Research in English Education. 2016 Vol. 1, No. 1. URL: http://ijreeonline.com/article-1-23-en.pdf

10. Chang L. Y. H. Group Processes and EFL Learners' Motivation: A Study of Group Dynamics in EFL Classrooms. TESOL Quarterly 44, 2010, p. 129-154. doi:10.5054/tq.2010.213780

11. Ditual R. C. The Motivation for and Attitude towards Learning English. Asian EFL Journal Press 2012, 63. p. 4-21.

12. Dornyei Z., Ushioda E. Teaching and Researching Motivation. Applied Linguistics in Action Series. $2^{\text {nd }}$ edition, Pearson Education Limited. 2011. URL: https://archive.org/stream/ilhem_20151031_1015/\%5BZolt\%C3\%A1n_D \%C3\%B6rnyei\%2C_Ema_Ushioda\%5D_Teaching_and_Resea_djvu.txt

13. Oxford University Press (2020). Motivation. Oxford Advanced Learner's Dictionary. URL: https://www.oxfordlearnersdictionaries.com/definition/english/motivation? $\mathrm{q}=$ motivation 